\title{
Морфологические проявления постледниковой сейсмической активности Имандра-Колвицкого активного разлома в Лувеньгской очаговой зоне (Мурманская область)
}

\author{
Шварев С.В. ${ }^{1,2}$, Николаева С.Б. ${ }^{3}$, Королева А.О. ${ }^{2,1}$ \\ ${ }^{1}$ Институт географии РАН, Москва, shvarev@igras.ru \\ ${ }^{2}$ Институт физики Земли им. О.Ю. Шмидта РАН, Москва, shvarev@ifz.ru,kao@ifz.ru \\ ${ }^{3}$ Геологический институт КНЦ РАН, Anamumbl, nikolaeva@geoksc.apatity.ru
}

\begin{abstract}
Аннотация. Представлены результаты палеосейсмогеологических исследований на юго-западе Кольского региона (СВ Фенноскандинавского щита). Изучение различных групп сейсмонарушений в районе детального изучения участка Лувеньгских тундр, а также морфотектонические данные, позволили выделить крупную Имандро-Колвицкую сейсмотектоническую зону, прослеживающуюся от западной части оз. Бабинская Имандра до Колвицкого озера и Умбинской губы, протяженностью более 100 км. Предварительные данные по оценке возраста палеосейсмодислокаций свидетельствуют о неоднократной активизации зоны разлома в поздне- и послеледниковое время. Интенсивность постледниковых землетрясений, судя по размерам первичных и вторичных сейсмогенных деформаций, могла достигать IX+ баллов.

Ключевые слова: активный разлом, палеосейсмодислокации, Лувеньгские тундры, Кольский полуостров, новейший грабен, очаговая зона палеоземлетрясений.

\section{Morphological manifestations of postglacial seismic activity of the Imandra-Kolvitsky active fault in the Luvenga focal zone (Murmansk region)}

\author{
Shvarev S.V. ${ }^{1,2}$, Nikolaeva S.B. ${ }^{3}$, Koroleva A.O. ${ }^{2,1}$ \\ ${ }^{1}$ Institute of Geography RAS, Moscow, shvarev@igras.ru \\ 2Schmidt Institute of Physics of the Earth,Moscow, shvarev@ifz.ru,kao@ifz.ru \\ ${ }^{3}$ Geological Institute of Kola Science Center RAS, Apatity,nikolaeva@geoksc.apatity.ru
}

\begin{abstract}
The results of paleo-seismological studies in the southwest of the Kola region (northeastern Fennoscandian shield) are presented. The study of various groups of seismic dislocations in the detailed study area of the low-mountain massif of Luvenga, as well as morphotectonic data, made it possible to identify the large ImandroKolvitsky seismotectonic zone traced from the western part of the lake Babinskaya Imandra to Kolvitsky Lake and Umbinskaya Bay, more than $100 \mathrm{~km}$ long. Preliminary data on the estimation of the age of paleoseismic dislocations indicate the repeated activation of the fault zone in the Late- and Post-Glacial period. The intensity of postglacial earthquakes, judging by the size of the primary and secondary seismogenic deformations, could reach IX + points.

Key words: active fault, paleoseismic dislocations, Luvenga massif, Kola Peninsula, neotectonic graben, focal zone of paleoearthquakes.
\end{abstract}

\section{Введение и постановка задачи}

В последние годы почти ни у кого не вызывает сомнения сильная постледниковая сейсмичность Фенноскандии, наиболее ярким выражением которой в рельефе являются протяженные (более 100 км) эшелонированные разломы, с видимой в уступах амплитудой вертикальных смещений в несколько метров. Такие разломы сосредоточены в основном в северо-западной Фенноскандии на территории северной Финляндии, Норвегии и Швеции. На восточной окраине Фенноскандии до сих пор линейных структур значительной протяженности с характерными признаками активности (палеосейсмодислокациями), которые можно было бы классифицировать как активный разлом, достоверно выявлено не было. Хотя обнаруженные к настоящему моменту многочисленные сейсмогенные нарушения (Николаева, 2001; Лукашов и др., 2004; Николаева, Евзеров, 2018; 2009; Верзилин, Бобков, 2009; Лукашов, Романенко, 2010; Николаева и др., 2016), послужили основой для выделения нескольких протяженных сейсмолинеаментов (Никонов, Шварев, 2015). Крупнейшие из них в 


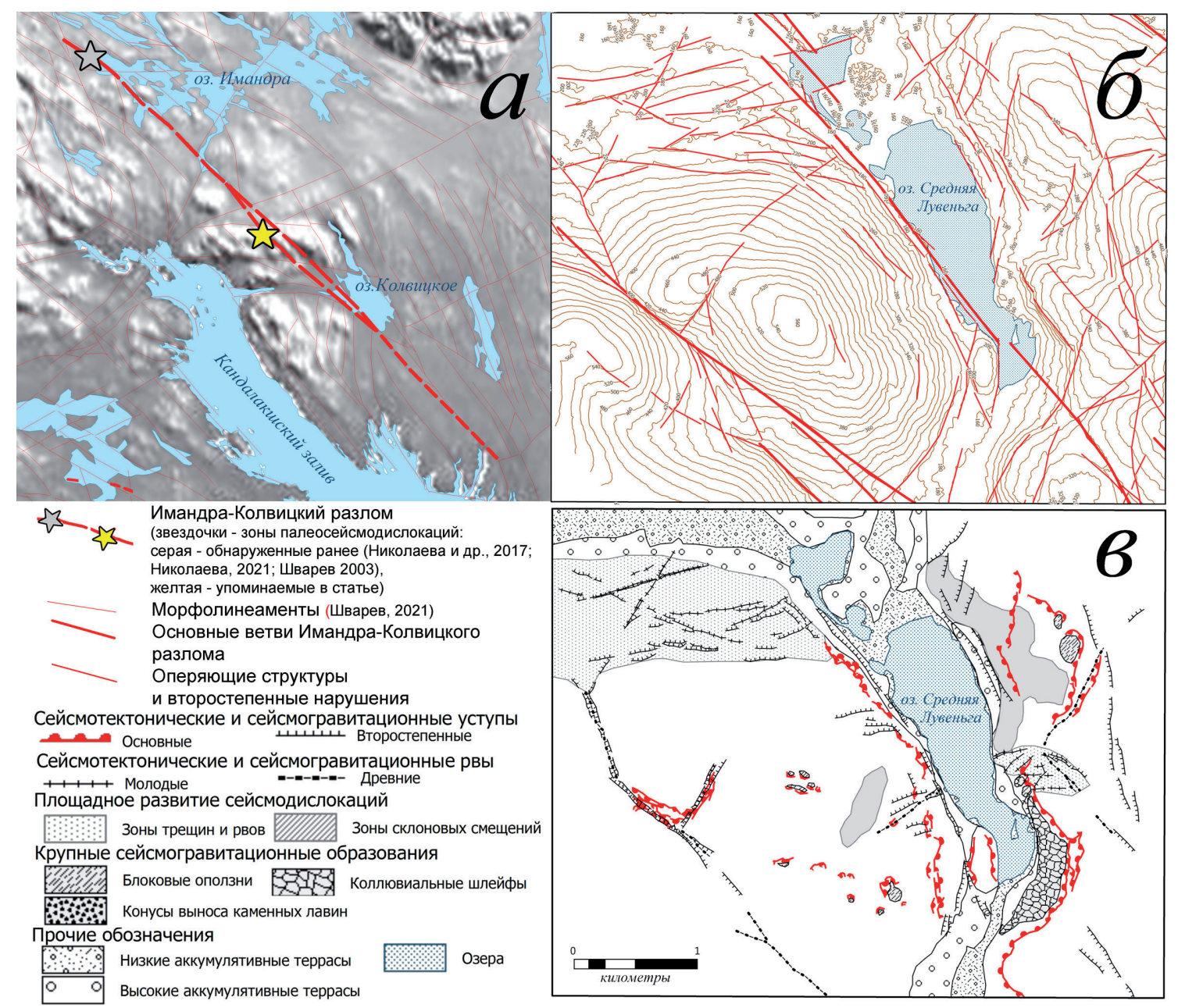

Рис. Положение и морфологические признаки Имандра-Колвицкого разлома: а) положение ИмандраКолвицкого активного разлома и места сосредоточения палеосейсмодеформаций в рельефе и рыхлых отложениях; б) цифровая модель рельефа (по данным ArcticDEM) и основные морфологически выраженные тектонические нарушения на пересечении Имандра-Колвицкого разлома и массива Лувеньгских Тундр; в) схема палеосейсмодислокаций в Средне-Лувеньгской очаговой зоне палеоземлетрясений.

Fig. Position and morphological features of the Imandra-Kolvitsky fault: a) the position of the Imandra-Kolvitsky active fault and the places of concentration of paleoseismic dislocations in the relief and sediments; b) a digital model of the relief (according to ArcticDEM data) and the main morphologically pronounced tectonic disturbances at the intersection of the Imandra-Kolvitsky fault and the Luvenga Tundra massif; c) scheme of paleoseismic dislocations in the Middle Luvenga focal zone of paleoearthquakes.

районе Кольского полуострова отвечают границам Кольской глыбы (Мурманский и Кандалакшский). Структуры меньшего ранга, но также обладающие высоким сеймогенерирующим потенциалом, составляют новейший блоковый каркас Кольского полуострова, отчасти маскируемый акваториями озер или рыхлым чехлом.

Одной из основных задач палеосеймогеологических исследований на Кольском полуострове является поиск крупных активных структур на суше, способных генерировать сильные землетрясения, поверхностные проявления которых соответствовали бы наблюдаемым практически повсеместно (VIII+ баллов), их пространственная локализация, оконтуривание очаговых зон, установление периодичности сейсмических сотрясений (повторяемости) определенной силы и интенсивности.

В представленном сообщении приводятся новые данные по идентификации протяженной сейсмогенерирующей структуры, к которой приурочено массовое развитие деформаций в рельефе и рыхлых отложениях, которые по совокупности признаков являются следствием нескольких сильных землетрясений в поздне- и постледниковое время. 


\section{Материалы и методы}

Для выполнения поставленной задачи используется комплекс исследований, включающий морфотектоническое и морфодинамическое дешифрирование для идентификации разрывных структур и связанных с ними проявлений экзогенеза, выявление очаговых зон, как закономерных пространственных сочетаний структурно-тектонических и геоморфологических признаков; натурное исследование очаговых зон с установлением пространственно-кинематических параметров сейсмогенерирующих структур и порождаемых ими сейсмодислокаций, поиск и опробование материалов для установления возраста сейсмических событий (радиоуглеродный анализ), пространственное моделирование в ГИС-среде (2D и 3D-модели на основе сопоставления топографических и геологогеоморфологических карт (масштабов 1:100000-1:1млн), космических снимков с разрешением 5-30 м (Sentinel, Landsat-ETM+) и цифровых моделей рельефа с разрешением 2-10 м (ArcticDEM)).

\section{Структурно-геологическое и морфоструктурное положение}

Низкогорный массив Лувеньгских тундр расположен на северо-западном замыкании Колвицкого коллизионного меланжа, юго-восточной части Лапландско-Колвицкого гранулитового пояса и сложен габбро-анортозитами, основными и средними гранулитами и амфиболитами, надвинутыми на окружающими массив по периферии верхнеархейскими гранитогнейсами Беломорского составного террейна (Балаганский и др., 2016). В оценке разрывной тектоники, как древней, так и новейшей, определяющей блоковое строение территории, согласно трактуется только положение, возраст и роль надвиговых структур по периферии массива. Сравнение основных схем разрывной тектоники (Козлов, 1979; Шенкман, 1991; Митрофанов, 1996; Балуев, 2010) показывает существенное расхождение в пространственном положении отдельных структур, определении их иерархии, структурной роли и активности. Суммируя данные по разрывной тектонике, можно четко выделить структуры обрамления массива, разделяющие основные структурно-фациальные комплексы и имеющие характерную дуговую форму, надвиговую кинематику и древнее заложение и наложенную систему диагональных разрывов северо-западного и северо-восточного простирания, секущих и смещающих более древние разломы и имеющих более молодой возраст, сдвиговый и сбросовый характер смещений. Этими характеристиками определяется и морфоструктурная роль систем разломов: возвышенный низкогорный структурно-денудационный массив Лувеньгских тундр оформлен в виде единой возвышенности за счет совокупного эффекта надвиговых смещений и ослабленной селективной денудации по отношению к окружающим структурам Беломорского пояса, и разбит на блоки, границы между которыми выражены сквозными долинами, наследующими зоны дробления или локально тектонически опущенные участки в зонах грабенов (возможно, имеющих присдвиговую природу (Колодяжный и др., 2019)).

\section{Результаты исследований}

Морфотектоническое дешифрирование материалов дистанционного зондирования позволило выделить сеть потенциально активизированных разрывных нарушений. Массив Лувеньгских тундр обрамлен с севера и юга субширотными, относительно короткими разрывами, наследующими палеопротерозойские надвиги, а с запада и востока - транзитными нарушениями С3-простирания. Разломы этого направления рассекают массив на серию блоков шириной 3-5 км, а крупнейший из них делит массив на западную (собственно Лувеньгские Тундры) и восточную (Елки-Тундры) части. Этот разлом прослеживается на северо-запад по озерным котловинам оз. Пинозеро, оз. Бабинская Имандра вплоть до западной оконечности последнего и замыкается в 10 км к С3. К юго-востоку разлом трассируется вдоль западного побережья Колвицкого озера и далее по системе линейных котловин до Умбинской губы. Общая протяженность разлома достигает 150 км, а протяженность его в качестве его как единой неразрывной структуры от озера Имандра до оз. Колвица - около 100 км. На западном замыкании разлома ранее были обнаружены следы палеоземлетрясений в донных отложениях озер (Николаева и др., 2017) и постледниковых тектонических деформаций поверхностей и отложений озерно-ледниковых и озерных террас (Шварев, 2003; Николаева, 2021). На пересечении с 
массивом Лувеньгских тундр в зоне разлома, образующего несколько параллельных ветвей, наблюдается концентрация первичных (сейсмотектонических) и вторичных (сейсмогравитационных) дислокаций, отражающих очаговую зону палеоземлетрясений высокой интенсивности. Центральная часть очаговой зоны, определяемая осевым сегментом Имандра-Колвицкого разлома - грабен, занятый котловиной оз. Среднее Лувеньгское. Магистральные бортовые разрывы характеризуются как постледниковые сбросы с амплитудой до первых десятков метров, а оперяющие разрывы формируют по восточной периферии очаговой зоны систему водораздельных рвов и обрамляют сейсмогравитационные шлейфы, превышающие по протяженности 1 км. Характерными вторичными дислокациями являются блоковые оползни и каменные лавины. Западная часть очаговой зоны определяется сквозной долиной, наследующей юго-западный сегмент Имандра-Колвицкого разлома с приразломной трещиной-ущельем протяженностью более 0.5 км, а северная периферия - системой оперяющих разрывов, деформирующих предгорную ступень массива Лувеньгских тундр диагонально сопряженными структурами растяжения - сбросовыми уступами и рвами с размахом высот в первые метры (до первых десятков метров) протяженностью в первые сотни метров. Предварительные данные по оценке возраста палеосейсмогенного очага свидетельствуют о неоднократной активизации Имандра-Колвицкого разлома, проявлявшейся как до последнего оледенения, следы которого нарушают формы сейсмогенного рельефа, так и в постледниковое время. По ранее полученным предварительным данным (Николаева и др., 2020) о возрасте нарушенных донных отложений близлежащих озер и захороненной под обвальными накоплениями почвы, можно утверждать, что в голоцене разлом активизировался не менее 3-х раз. Интенсивность постледниковых землетрясений, судя по размерам первичных и вторичных сейсмогенных деформаций, могла достигать IX+ баллов.

\section{Выводы}

1. В ЮЗ части Кольского полуострова выделена протяженная (> 100 км) сейсмогенерирующая структура (Имандра-Колвицкий разлом).

2. Сейсмодислокации очаговой зоны в массиве Лувеньгские тундры включают сейсмотектонические и сейсмогравитационные проявления, характерные для землетрясений с интенсивностью IX+ баллов.

3. Обнаружены признаки неоднократной сейсмогенной активизации в до- и постледниковое время.

Работа выполнена в рамках тем госзаданий ИГ РАН №0148-2019-0005, ИФЗ РАН № 0144-2019-0010 и ГИ КНЦ РАН № 0226-2019-0054.

\section{Литература}

4. Балаганский В.В., Горбунов И.А., Мудрук С.В. Палеопротерозойские Лапландско-Кольский и Свекофеннский орогены (Балтийский щит) / // Вестник Кольского научного центра РАН. 2016. № 3(26). С. 5-11.

5. Балуев А.С. Тектоническая карта Белого моря и прилегающих территорий. Масштаб 1:1500000. М. Изд-во: ГИН РАН. 2010.

6. Верзилин Н.Н., Бобков А.А. Следы голоценовых землетрясений на севере Кольского полуострова // Геология, геоэкология, эволюционная география. СПб. 2009. С. 20-25.

7. Козлов М.Т. Разрывная тектоника северо-восточной части Балтийского щита. Л. Изд-во: Наука. 1979. $140 \mathrm{c}$.

8. Колодяжный С.Ю., Балуев А.С., Зыков Д.С. Структура и эволюция северо-запада БеломорскоСеверодвинской зоны сдвига в позднем протерозое и фанерозое (Восточно-Европейская платформа) // Геотектоника. 2019. № 1. С. 62-86. doi:10.31857/S0016-853Х2019162-86.

9. Лукашов А.А., Кузнецов Д.Е., Романенко Ф.А. Геоморфологические признаки позднеголоценовой сейсмической активности восточной части Хибинского массива (Кольский полуостров) // Геодинамика и геологические изменения в окружающей среде северных регионов. 2004. Т. ІІ. С. 25-29.

10. Лукашов А.А., Романенко Ф.А. Характер и морфодинамика дизъюнктивного северо-восточного ограничения Балтийского щита («линии Карпинского») // Тектоника и геодинамика складчатых поясов и платформ фанерозоя. Материалы XLIII Тектонического совещания. Т. 1. М. Изд-во: ГЕОС. 2010. С. 430-434. 
11. Митрофанов Ф.П. Геологическая карта Кольского региона масштаба 1:500000. Ред. А.П. Радченко (Россия), К. Гиллен (Великобритания). Авторы-составители В.В. Балаганский, А.А. Басалаев, О.А. Беляев, В.И. Пожиленко, А.Т. Радченко, М.К. Радченко. Апатиты, 1996. Испр. и дополн. В.И. Пожиленко. 2001.

12. Николаева С.Б. Палеосейсмические проявления в северо-восточной части Балтийского щита и их геолого-тектоническая позиция // Геоморфология. 2001. № 4. С. 66-74.

13. Николаева С.Б. Сейсмиты в позднеплейстоцен-голоценовых осадках северо-запада Кольского региона (северная часть Балтийского щита) // Геология и геофизика. 2009. Т. 50. № 7. С. 830-839.

14. Николаева С.Б. Евзеров В.Я. К геодинамике Кольского региона в позднем плейстоцене и голоцене: обзор и результаты исследований // Вестник ВГУ. Сер. Геология. 2018. №1. С. 5-14.

15. Николаева С.Б., Лаврова Н.Б., Денисов Д.Б. Катастрофическое событие голоцена в донных осадках озер Кольского полуострова (СВ Фенноскандинавского щита) // ДАН. 2017. Т. 473. № 1. С. 88-92. doi: $10.7868 / \mathrm{S} 0869565217070209$.

16. Николаева С.Б. Отражение палеосейсмических событий в позднеплейстоцен-голоценовых отложениях террас озера Имандра (Кольский регион) // Геоморфология. 2021. №1. С. 86-99. doi: 10.31857/ s0435428121010119.

17. Николаева С.Б., Никонов А.А., Шварев С.В., Родкин М.В. Комплексные палеосейсмогеологические исследования на ключевом участке в юго-западной части Кольского полуострова (северо-восток Фенноскандинавского щита) // ДАН. 2016. Т 469. № 2. С. 199-203. doi: 10.7868/S0869565216200172.

18. Николаева С.Б., Толстобров Д.С., Вашков А.А. Палеосейсмогеологические исследования в европейской субарктике (Кольский регион): полевые экспедиционные работы 2018-2020 гг. // Рельеф и четвертичные образования Арктики, Субарктики и Северо-Запада России. Вып. 7. 2020 С. 129-133. doi:10.24411/2687-1092-2020-10719.

19. Никонов А.А., Шварев С.В. Сейсмолинеаменты и разрушительные землетрясения в российской части Балтийского щита: новые решения для последних 13 тыс. лет // Матер. Международной конференции «Геолого-геофизическая среда и разнообразные проявления сейсмичности». Нерюнгри. Изд-во: Техн. Ин-та (ф) СВФУ. 2015. С. 243-251.

20. Шварев С.В. Послеледниковые тектонические движения и формирование террас оз. Имандра (Кольский полуостров) // Геоморфология. 2003. № 4. С. 97-105.

21. Шенкман Е.Я. Геодинамическая карта Кольского полуострова. М-б 1:500000. Мингео СССР. НПО «Аэрогеология». МОМКАГЭ. 1991. 7 л. 